\title{
Super Silyl Group for a Sequential Diastereoselective Aldol- Polyhalomethyllithium Addition Reaction
}

Matthew Boxer and Hisashi Yamamoto*

\section{SUPPORTING INFORMATION}

\section{Experimental Section}

All non-aqueous reactions were carried out in flame-dried glassware under nitrogen atmosphere and stirred via magnetic stir-plates. All reactions were monitored by analytical thin-layer chromatography using Merck pre-coated silica gel plates with $\mathrm{F}_{254}$ indicator. Visualization was accomplished by UV light $(256 \mathrm{~nm})$, potassium permanganate, phosphomolybdic acid, iodine, or anisaldehyde. Flash column chromatography was performed according to the method of Still using silica gel 60 (mesh 230-400) supplied by E. Merck. All reactions were carried out with anhydrous solvents unless otherwise noted. Anhydrous THF, dichloromethane, diethyl ether and hexane were dried with a M BRAUN solvent purification system (A2 Alumina). Brine refers to a saturated aqueous solution of sodium chloride. All other reagents and starting materials, unless otherwise noted, were purchased from commercial vendors and used without further purification. Infrared spectra were recorded as thin films on sodium chloride plates using a Nicolet 20 SXB FTIR. ${ }^{1} \mathrm{H}$ NMR and ${ }^{13} \mathrm{C}$ NMR spectra were recorded on a Bruker Avance $400\left(400 \mathrm{MHz}{ }^{1} \mathrm{H}, 100 \mathrm{MHz}{ }^{13} \mathrm{C}\right)$, or a Bruker Avance 500 $\left(500 \mathrm{MHz}{ }^{1} \mathrm{H}, 125 \mathrm{MHz}{ }^{13} \mathrm{C}\right)$. Chemical shift values $(\delta)$ are reported in ppm (residual chloroform $\delta 7.26 \mathrm{ppm}$ for ${ }^{1} \mathrm{H} ; \delta 77.0 \mathrm{ppm}$ for ${ }^{13} \mathrm{C}$. The proton spectra are reported as follows $\delta$ (multiplicity, number of protons, coupling constant $J$ ). Multiplicities are indicated by s (singlet), d (doublet), t (triplet), q (quartet), dd (doublet of doublet), ddd (doublet of doublet of doublet), m (multiplet) and br (broad).

Chemicals: tris(trimethylsilyl)silane, all aldehydes (unless otherwise noted), $n$-BuLi, pyridine, triethylamine, acetic anhydride, chloroform, bromoform, dibromomethane, 
diiodomethane, and $\mathrm{HNTf}_{2}$ were purchased from Aldrich. All aldehydes, chloroform, pyridine, bromoform, diiodomethane, and dibromomethane were distilled prior to use. tris(trimethylsilyl)silyl enol ether was synthesized as previously reported ${ }^{1}$ The silyl enol ether was stored in a freezer $\left(-30{ }^{\circ} \mathrm{C}\right)$ between uses.

\section{Typical Preparation of Stock Solution of Lithium amide (0.5 M)}

The lithium amide was prepared as a stock solution during the day of use and was suitable for reactions for up to $4 \mathrm{~h}$ after preparation.

2,2,6,6-tetramethylpiperidine $(844 \mu \mathrm{l}, 5.0 \mathrm{mmol})$ was dissolved in THF $(5.35 \mathrm{ml})$ and cooled to $0{ }^{\circ} \mathrm{C}$. To this stirring solution was added $n$-BuLi $(2.8 \mathrm{ml}$ of a $1.6 \mathrm{M}$ hexane solution, $4.5 \mathrm{mmol}$ ) dropwise. After stirring at $0{ }^{\circ} \mathrm{C}$ for $30 \mathrm{~min}$, the light yellow solution was ready for use.

\section{Typical Procedure for Table 1 entry 7 and Table 2 entries 5 - 7}

Table 1, entry 7 as example. The acetaldehyde super silyl enol ether (290 mg, 1.0 $\mathrm{mmol})$ and 2-phenylpropanal $(135 \mu \mathrm{l}, 1.0 \mathrm{mmol})$ were dissolved in dichloroethane $(2 \mathrm{ml})$ under nitrogen atmosphere and cooled to $-30{ }^{\circ} \mathrm{C}$. $\operatorname{HNTf}_{2}(100 \mu \mathrm{l}$ of a $5 \mathrm{mM}$ dichloroethane solution) was added dropwise and the reaction was stirred at $-30{ }^{\circ} \mathrm{C}$ for 15 min. The reaction mixture was diluted with THF $(8 \mathrm{ml})$ and dibromomethane $(350 \mu 1,5.0$ mmol) was added. The solution was cooled to $-100{ }^{\circ} \mathrm{C}$. LiTMP $(5 \mathrm{ml}$ of a $0.5 \mathrm{M}$ THF stock solution, $2.5 \mathrm{mmol})$ was added dropwise to the cold $\left(-100{ }^{\circ} \mathrm{C}\right)$ solution of in situ prepared aldehyde. The reaction was stirred at $-100{ }^{\circ} \mathrm{C}$ for $1 \mathrm{~h}$, quenched with saturated aqueous $\mathrm{NH}_{4} \mathrm{Cl}$ and warmed to room temperature. The mixture was diluted with hexane $(10 \mathrm{ml})$ and organic layer was washed twice with saturated aqueous $\mathrm{NH}_{4} \mathrm{Cl}(2 \times 10 \mathrm{ml})$, once with brine $(10 \mathrm{ml})$ and then dried over sodium sulfate. Silica gel flash column chromatography was done with 99/1 hexane/EtOAc (v/v) as the eluant.

\section{Typical Procedure for Table 2 entries 1 and 2}

Entry 1 as example. The acetaldehyde super silyl enol ether (290 mg, $1.0 \mathrm{mmol})$ and 2phenylpropanal $(135 \mu 1,1.0 \mathrm{mmol})$ were dissolved in dichloromethane $(2 \mathrm{ml})$ under nitrogen atmosphere and cooled to $-78{ }^{\circ} \mathrm{C}$. $\operatorname{HNTf}_{2}(100 \mu \mathrm{l}$ of a $5 \mathrm{mM}$ dichloromethane 
solution) was added dropwise and the reaction was stirred at $-78{ }^{\circ} \mathrm{C}$ for $15 \mathrm{~min}$. The reaction mixture was diluted with THF $(8 \mathrm{ml})$ and cooled to $-100{ }^{\circ} \mathrm{C}$. LiTMP $(5 \mathrm{ml}$ of a 0.5 M THF stock solution, $2.5 \mathrm{mmol})$ was added dropwise to the cold $\left(-100{ }^{\circ} \mathrm{C}\right)$ solution of in situ prepared aldehyde. The reaction was stirred at $-100{ }^{\circ} \mathrm{C}$ for $1 \mathrm{~h}$, quenched with saturated aqueous $\mathrm{NH}_{4} \mathrm{Cl}$ and warmed to room temperature. The mixture was diluted with hexane $(10 \mathrm{ml})$ and organic layer was washed twice with saturated aqueous $\mathrm{NH}_{4} \mathrm{Cl}(2 \mathrm{x}$ $10 \mathrm{ml}$ ), once with brine $(10 \mathrm{ml})$ and then dried over sodium sulfate. Silica gel flash column chromatography was done with $99 / 1$ hexane/EtOAc (v/v) as the eluant.

\section{Typical Procedure for Table 2 entry 3}

The acetaldehyde super silyl enol ether $(290 \mathrm{mg}, 1 \mathrm{mmol})$ and hydrocinnamaldehyde (132 $\mu 1,1.0 \mathrm{mmol})$ were dissolved in freshly distilled chloroform $(2 \mathrm{ml})$ under nitrogen atmosphere at RT. $\mathrm{HNTf}_{2}(100 \mu \mathrm{L}$ of a $5 \mathrm{mM}$ dichloroethane solution) was added dropwise and the reaction was stirred at RT for $15 \mathrm{~min}$. The reaction mixture was diluted with THF $(8 \mathrm{ml})$ and cooled to $-100{ }^{\circ} \mathrm{C}$. LiTMP $(5 \mathrm{ml}$ of a $0.5 \mathrm{M}$ THF stock solution, 2.5 mmol) was added dropwise to the cold $\left(-100{ }^{\circ} \mathrm{C}\right)$ solution of in situ prepared aldehyde. The reaction was stirred at $-100{ }^{\circ} \mathrm{C}$ for $1 \mathrm{~h}$, quenched with saturated aqueous $\mathrm{NH}_{4} \mathrm{Cl}$ and warmed to room temperature. The mixture was diluted with hexane $(10 \mathrm{ml})$ and organic layer was washed twice with saturated aqueous $\mathrm{NH}_{4} \mathrm{Cl}(2 \times 10 \mathrm{ml})$, once with brine $(10$ $\mathrm{ml}$ ) and then dried over sodium sulfate. Silica gel flash column chromatography was done with 99/1 hexane/EtOAc (v/v) as the eluant.

1.

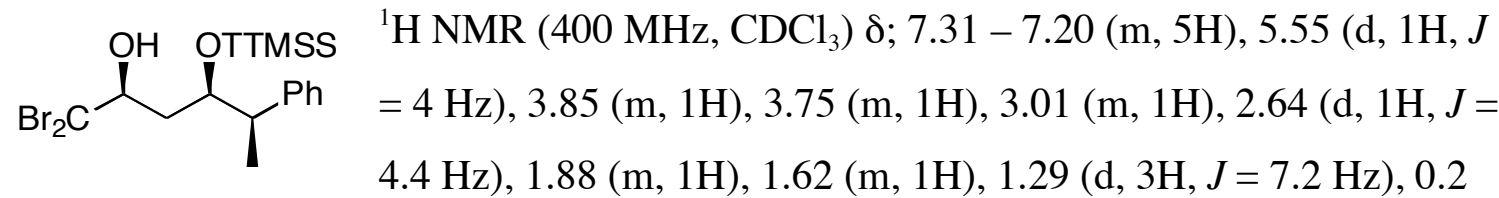

(s, 27H); ${ }^{13} \mathrm{C}$ NMR (100 MHz, $\left.\mathrm{CDCl}_{3}\right) \delta ; 143.5,128.3,128.1,126.3$, 78.6, 74.2, 52.4, 43.5, 37.8, 15.1, 0.7; IR (film) 3567, 2948, 2892, 1244, 1081, 1025, 835; MS (EI) (M+) 596.1 . 
2.

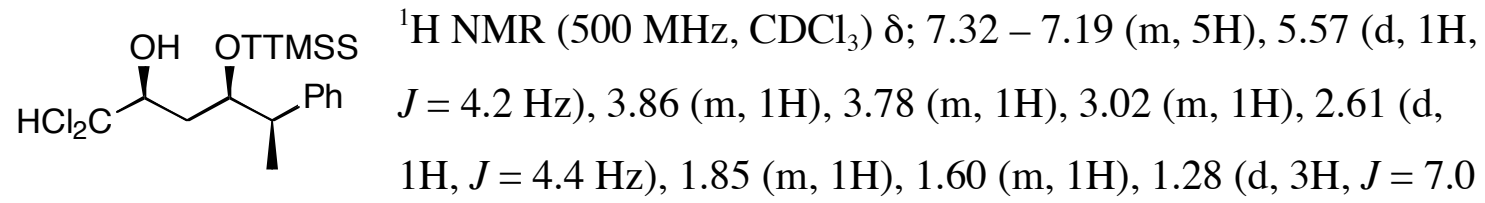
$\mathrm{Hz}), 0.2$ (s, 27H); $\left.{ }^{13} \mathrm{C} \mathrm{NMR} \mathrm{(100} \mathrm{MHz,} \mathrm{CDCl}_{3}\right)$ \&; 143.5, 128.3, 128.1, 126.3, 78.6, 76.5, 74.1, 43.5, 36.2, 15.2, 0.7; IR (film) 3585, 3470, 3028, 2948, 2894, 2360, 2340, 1452, 1245, 1082, 836; MS (EI) (M+) 508.2.

3.

$\mathrm{OH}$ OTTMSS ${ }^{1} \mathrm{H} \mathrm{NMR}\left(500 \mathrm{MHz}, \mathrm{CDCl}_{3}\right) \delta ; 5.69(\mathrm{~d}, 1 \mathrm{H}, J=5 \mathrm{~Hz}), 3.95(\mathrm{~m}$, $1 \mathrm{H}), 3.63(\mathrm{~m}, 1 \mathrm{H}), 3.47(\mathrm{~d}, 1 \mathrm{H}, J=4.8 \mathrm{~Hz}), 1.86(\mathrm{~m}, 1 \mathrm{H}), 1.70-$ $1.50(\mathrm{~m}, 3 \mathrm{H}), 1.09(\mathrm{~m}, 1 \mathrm{H}), 0.92(\mathrm{t}, 3 \mathrm{H}, J=6.5 \mathrm{~Hz}), 0.83(\mathrm{~d}, 3 \mathrm{H}, J$ $=7 \mathrm{~Hz}), 0.21(\mathrm{~s}, 27 \mathrm{H}) ;{ }^{13} \mathrm{C} \mathrm{NMR}\left(100 \mathrm{MHz}, \mathrm{CDCl}_{3}\right) \delta ; 80.1,75.9,75.4,39.4,32.7,23.1$, 14.5, 12.0, 0.7; IR (film) 3584, 3457, 2961, 2893, 1463, 1245, 1067, 836; MS (EI) (M+) 460.2 .

4.

OH OTTMSS ${ }^{1} \mathrm{H} \mathrm{NMR}\left(500 \mathrm{MHz}, \mathrm{CDCl}_{3}\right) \delta ; 7.31-7.17(\mathrm{~m}, 5 \mathrm{H}), 4.14(\mathrm{~m}, 1 \mathrm{H})$,

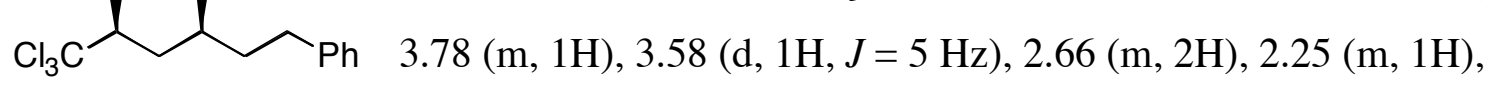
$1.86(\mathrm{~m}, 3 \mathrm{H}), 0.21(\mathrm{~s}, 27 \mathrm{H}) ;{ }^{13} \mathrm{C} \mathrm{NMR}\left(125 \mathrm{MHz}, \mathrm{CDCl}_{3}\right)$ \&; 141.7, 128.6, 128.3, 125.9, 81.1, 74.7, 50.1, 38.6, 37.5, 31.3, 0.5; IR (film) 3434, 2948, 2850, 1245, 1055, 836; MS (EI) $\left(\mathrm{M}^{+}\right) 542.1$.

5.

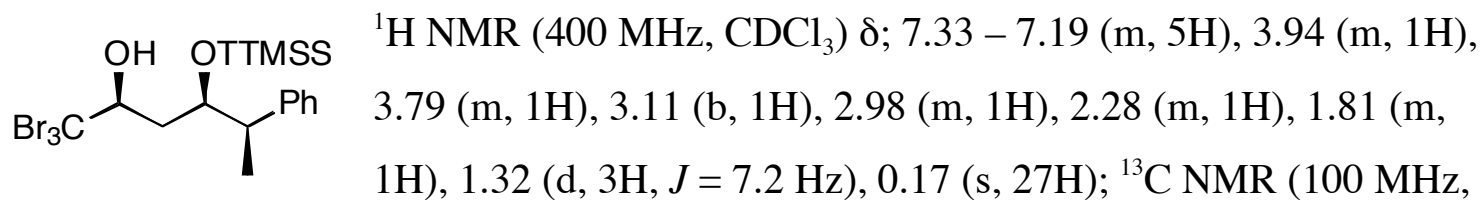


$\left.\mathrm{CDCl}_{3}\right) \delta ; 144.0,128.3,128.1,126.3,82.2,77.9,54.9,43.4,37.8,13.8,0.7$; IR (film)

3568, 3027, 2947, 2892, 1495, 1451, 1244, 1084, 836; MS (EI) (M+) 674.0.

6.

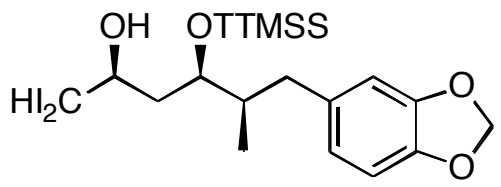

${ }^{1} \mathrm{H}$ NMR $\left(500 \mathrm{MHz}, \mathrm{CDCl}_{3}\right) \delta ; 6.72(\mathrm{~d}, 1 \mathrm{H}, J=7.5 \mathrm{~Hz})$, $6.66(\mathrm{~d}, 1 \mathrm{H}, J=1 \mathrm{~Hz}), 6.61(\mathrm{~d}, 1 \mathrm{H}, J=8 \mathrm{~Hz}), 5.92(\mathrm{~s}$, $2 \mathrm{H}), 5.18(\mathrm{~d}, 1 \mathrm{H}, J=3.5 \mathrm{~Hz}), 3.71\left(\mathrm{dt}, 1 \mathrm{H}, J_{1}=2.5 \mathrm{~Hz}\right.$,

$\left.J_{2}=7.3 \mathrm{~Hz}\right), 3.24(\mathrm{~m}, 1 \mathrm{H}), 2.84(\mathrm{~b}, 1 \mathrm{H}), 2.76\left(\mathrm{dd}, 1 \mathrm{H}, J_{1}=3.8 \mathrm{~Hz}, J_{2}=13.5 \mathrm{~Hz}\right), 2.33$ $\left(\mathrm{dd}, 1 \mathrm{H}, J_{1}=10.9 \mathrm{~Hz}, J_{2}=13.5 \mathrm{~Hz}\right), 1.94(\mathrm{~m}, 2 \mathrm{H}), 1.69(\mathrm{~m}, 1 \mathrm{H}), 0.76(\mathrm{~d}, 3 \mathrm{H}, J=7 \mathrm{~Hz})$, 0.25 (s, $27 \mathrm{H}) ;{ }^{13} \mathrm{C}$ NMR $\left(125 \mathrm{MHz}, \mathrm{CDCl}_{3}\right) \delta ; 147.4,145.6,134.8,121.9,109.5,108.0$, 100.7, 77.9, 75.1, 39.3, 38.9, 38.6, 12.8, 0.8, -11.4; IR (film) 3542, 2948, 2891, 1502, 1489, 1245, 836; MS (EI) (M+) 750.0.

7.

$$
\begin{aligned}
& =3.5 \mathrm{~Hz}), 3.82(\mathrm{~m}, 1 \mathrm{H}), 3.16(\mathrm{~m}, 1 \mathrm{H}), 3.01(\mathrm{~m}, 1 \mathrm{H}), 2.65(\mathrm{~d}, 1 \mathrm{H}, J \\
& =4.5 \mathrm{~Hz}), 1.84(\mathrm{~m}, 1 \mathrm{H}), 1.50(\mathrm{~m}, 1 \mathrm{H}), 1.28(\mathrm{~d}, 3 \mathrm{H}, J=7.1 \mathrm{~Hz}),
\end{aligned}
$$

0.21 (s, 27H); ${ }^{13} \mathrm{C}$ NMR (100 MHz, $\mathrm{CDCl}_{3}$ ) \&; 143.3, 128.3, 128.1, 126.4, 78.7, 75.0, 43.8, 40.1, 15.4, 0.8; IR (film) 3550, 3461, 3085, 3062, 3027, 2949, 2892, 1602, 1452, 1081, 837; MS (EI) $\left(\mathrm{M}^{+}\right) 692.0$.

\section{Typical Synthesis of $Z$-vinyl halides ${ }^{2}$}

1a. To a solution of 1 (500 mg, $0.84 \mathrm{mmol})$ in THF ( $3 \mathrm{ml})$ was added pyridine $(675 \mu \mathrm{l}$, $8.4 \mathrm{mmol})$ followed by acetic anhydride ( $400 \mu \mathrm{l}, 4.2 \mathrm{mmol})$ and a catalytic amount of DMAP (10 mg, $0.084 \mathrm{mmol})$. The mixture was stirred at room temperature overnight, then diluted with EtOAc $(5 \mathrm{ml})$ and quenched with saturated aqueous copper sulfate (5 $\mathrm{ml})$. The organic layer was washed twice with the saturated copper sulfate $(2 \times 5 \mathrm{ml})$, once with saturated $\mathrm{NaHCO}_{3}(5 \mathrm{ml})$ and once with brine $(5 \mathrm{ml})$. After drying over sodium sulfate the solvent was evaporated and the acetate was used without further purification. 
In a glove box, $\mathrm{SmI}_{2}(745 \mathrm{mg}, 1.8 \mathrm{mmol})$ was added to a flame dried flask with a stir bar, capped with a septa and removed from the glove box. The flask was fit with an argon balloon, THF $(2 \mathrm{ml})$ was added and the suspension was cooled to $0{ }^{\circ} \mathrm{C}$. The crude acetate was dissolved in THF $(2 \mathrm{ml})$ and added dropwise to the stirring solution of $\mathrm{SmI}_{2}$. The flask was removed from the cold bath and allowed to stir at room temperature for $2 \mathrm{~h}$, while being monitored by TLC. After completion, the reaction was quenched with $1 \mathrm{~N}$ $\mathrm{HCl}(3 \mathrm{ml})$ and diluted with EtOAc $(5 \mathrm{ml})$. The organic layer was washed once with $1 \mathrm{~N}$ $\mathrm{HCl}(5 \mathrm{ml})$, twice with saturated $\mathrm{NaHCO}_{3}(2 \times 5 \mathrm{ml})$, once with brine $(5 \mathrm{ml})$, dried over sodium sulfate and concentrated in vасио. Silica gel column chromatography was done with hexane as the eluant to yield pure $Z$-vinyl halide.

$1 a$.

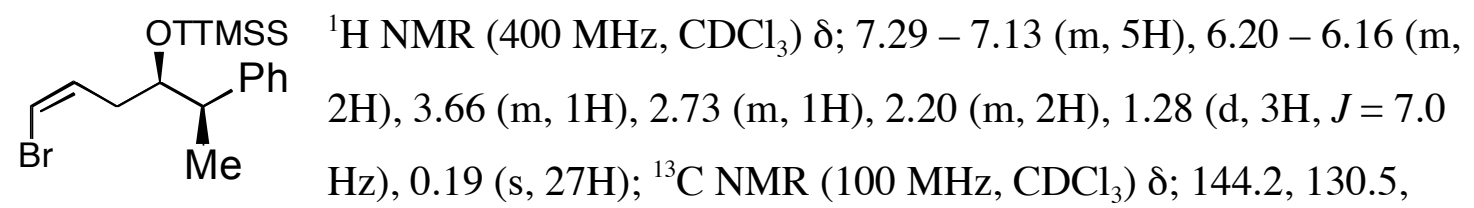
128.3, 128.1, 126.2, 109.1, 79.5, 44.7, 34.7, 17.5, 0.7; IR (film) 3028, 2949, 2894, 1494, 1244, 1076, 835; MS (EI) $\left(\mathrm{M}^{+}\right)$500.1.

3a.

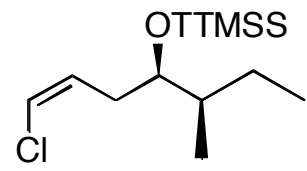

${ }^{1} \mathrm{H}$ NMR (400 MHz, $\left.\mathrm{CDCl}_{3}\right) \delta ; 6.09(\mathrm{~m}, 1 \mathrm{H}), 5.79(\mathrm{~m}, 1 \mathrm{H}), 3.38$ (m, 1H), $2.35(\mathrm{~m}, 2 \mathrm{H}), 1.51(\mathrm{~m}, 1 \mathrm{H}), 1.42(\mathrm{~m}, 1 \mathrm{H}), 1.11(\mathrm{~m}, 1 \mathrm{H}), 0.88-$ $0.72(\mathrm{~m}, 6 \mathrm{H}), 0.20(\mathrm{~s}, 27 \mathrm{H}) ;{ }^{13} \mathrm{C} \mathrm{NMR}\left(100 \mathrm{MHz}, \mathrm{CDCl}_{3}\right) \delta ; 128.8$, 188.9, 79.1, 39.7, 31.2, 24.7, 14.1, 12.0, 0.6; IR (film) 2960, 2894, 1463, 1381, 1244 , 1070, 836; MS (EI) $\left(\mathrm{M}^{+}\right) 408.2$.

6a.

${ }^{1} \mathrm{H}$ NMR $\left(500 \mathrm{MHz}, \mathrm{CDCl}_{3}\right) \delta ; 6.71(\mathrm{~d}, 1 \mathrm{H}, J=8 \mathrm{~Hz}), 6.62(\mathrm{~s}, 1 \mathrm{H}), 6.57$ (m, 1H), 6.29 (m, 1H), $6.22(\mathrm{~m}, 1 \mathrm{H}), 5.91(\mathrm{~m}, 2 \mathrm{H}), 3.49(\mathrm{~m}, 1 \mathrm{H}), 2.73(\mathrm{~m}, 1 \mathrm{H}), 2.38(\mathrm{~m}, 1 \mathrm{H}), 2.21(\mathrm{dd}$, $\left.1 \mathrm{H}, J_{1}=10.5 \mathrm{~Hz}, J_{2}=13 \mathrm{~Hz}\right), 1.69(\mathrm{~m}, 1 \mathrm{H}), 0.77(\mathrm{~d}, 3 \mathrm{H}, J=7.0 \mathrm{~Hz}), 0.21(\mathrm{~s}, 27 \mathrm{H}) ;{ }^{13} \mathrm{C}$ NMR (100 MHz, $\left.\mathrm{CDCl}_{3}\right) \delta ; 147.4,145.5,138.0,135.1,121.9,109.4,107.9,100.7,83.7$, 


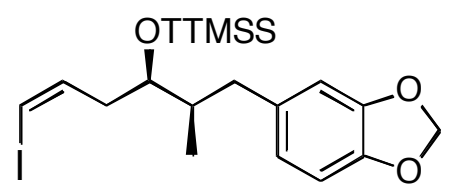

78.4, 40.3, 39.3, 38.8, 13.9, 0.7; IR (film) 2961, 2892, 1463,

$1381,1244,1071,836 ; \mathrm{MS}(\mathrm{EI})\left(\mathrm{M}^{+}\right) 606.1$.

\section{Synthesis of Vinylidene Dichloride ${ }^{3}$}

At room temperature, 4 (300 mg, $0.55 \mathrm{mmol})$ was dissolved in dichloromethane (3 ml) and $\mathrm{Et}_{3} \mathrm{~N}(180 \mu \mathrm{l}, 1.3 \mathrm{mmol})$ was added, followed by addition of methanesulfonyl chloride $(85 \mu \mathrm{l}, 1.1 \mathrm{mmol})$. The solution was stirred at room temperature for $2 \mathrm{~h}$, and quenched with $\mathrm{NaHCO}_{3}(5 \mathrm{ml})$. The organic layer was washed three times with $\mathrm{NaHCO}_{3}$ ( $3 \times 5 \mathrm{ml}$ ), once with brine and dried over sodium sulfate. The solvent was removed in vacuo and then the crude mesylate was dissolved in dry DMF $(3 \mathrm{ml})$ and indium powder (70 mg of 100 mesh, $0.6 \mathrm{mmol}$ ) was added. The suspension was heated to reflux at $\sim 160$ ${ }^{\circ} \mathrm{C}$ for $3 \mathrm{~h}$ while being monitored by TLC. After completion the mixture was cooled to RT and quenched with saturated $\mathrm{NH}_{4} \mathrm{Cl}(5 \mathrm{ml})$ and extracted with three times with $\mathrm{Et}_{2} \mathrm{O}$ (3 x $5 \mathrm{ml})$. The organic extracts were combined, washed once with brine $(5 \mathrm{ml})$, dried over sodium sulfate and the solvent removed in vacuo. Purification by silica gel chromatography was performed with hexane as the eluant.

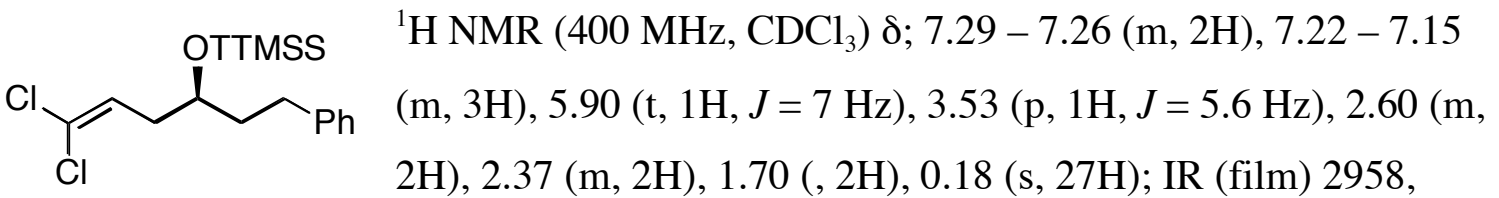
2887, 1464, 1381, 1244, 1070, 836; MS (EI) (M+) 490.2.

\section{Synthesis of $\mathbf{8}^{4}$}

The acetaldehyde super siyl enol ether $(290 \mathrm{mg}, 1.0 \mathrm{mmol})$ and aldehyde (135 $\mu 1,1.0$ $\mathrm{mmol})$ were dissolved in dichloroethane $(2 \mathrm{ml})$ under nitrogen atmosphere and cooled to $-30{ }^{\circ} \mathrm{C} . \mathrm{HNTf}_{2}(100 \mu \mathrm{L}$ of a $5 \mathrm{mM}$ dichloroethane solution) was added dropwise and the reaction was stirred at $-30{ }^{\circ} \mathrm{C}$ for $15 \mathrm{~min}$. THF $(15 \mathrm{ml}), \mathrm{Et}_{2} \mathrm{O}(8 \mathrm{ml})$ and $\mathrm{CFBr}_{3}(490 \mu \mathrm{l}$, $5.0 \mathrm{mmol}$ ) were then added and the solution was cooled to $-130{ }^{\circ} \mathrm{C}$. To the stirring solution was added $n-\mathrm{BuLi}$ ( $2.8 \mathrm{ml}$ of a $1.6 \mathrm{M}$ hexane solution, $4.5 \mathrm{mmol}$ ) dropwise. The solution was stirred for 30 minutes at $-130{ }^{\circ} \mathrm{C}$ and then warmed to $-78{ }^{\circ} \mathrm{C}$ and stirred an additional $30 \mathrm{~min}$. The solution was then quenched with saturated aqueous $\mathrm{NH}_{4} \mathrm{Cl}$ and warmed to room temperature. The mixture was diluted with hexane $(10 \mathrm{ml})$ and organic 
layer was washed twice with saturated aqueous $\mathrm{NH}_{4} \mathrm{Cl}(2 \times 10 \mathrm{ml})$, once with brine (10 $\mathrm{ml}$ ) and then dried over sodium sulfate. Silica gel flash column chromatography was done with 99/1 hexane/EtOAc (v/v) as the eluant.

\section{8.}

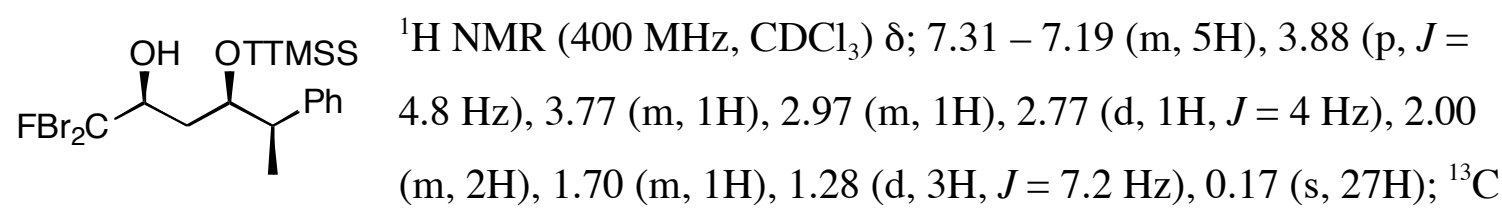

NMR (100 MHz, $\left.\mathrm{CDCl}_{3}\right) \delta ; 143.6,128.2,128.2,126.4,103.1$ (d, $\left.C F, J=300 \mathrm{~Hz}\right), 79.1$

(d, $C F, J=20 \mathrm{~Hz}$ ), 77.9, 43.7, 36.5, 14.9, 0.7; IR (film) 2960, 2894, 1463, 1381, 1244, 1070, 836; MS (EI) $\left(\mathrm{M}^{+}\right) 614.1$.

\section{Synthesis of $9^{5}$}

To a solution of 8 (450 mg, $0.73 \mathrm{mmol})$ in THF $(2.5 \mathrm{ml})$ was added pyridine $(590 \mu \mathrm{l}, 7.3$ mmol) followed by acetic anhydride $(350 \mu \mathrm{l}, 3.7 \mathrm{mmol})$ and a catalytic amount of DMAP (9 $\mathrm{mg}, 0.073 \mathrm{mmol})$. The mixture was stirred at room temperature overnight, then diluted with EtOAc $(5 \mathrm{ml})$ and quenched with saturated aqueous copper sulfate $(5 \mathrm{ml})$. The organic layer was washed twice with the saturated copper sulfate $(2 \times 5 \mathrm{ml})$, once with saturated $\mathrm{NaHCO}_{3}(5 \mathrm{ml})$ and once with brine $(5 \mathrm{ml})$. After drying over sodium sulfate the solvent was evaporated and the acetate was used without further purification. $\mathrm{CrCl}_{2}$ (273 mg, $2.2 \mathrm{mmol}$ ) was suspended in anhydrous THF $(5 \mathrm{ml})$ at RT and the crude acetate in THF ( $2 \mathrm{ml}$ ) was added dropwise. The mixture was refluxed for $3 \mathrm{~h}$, cooled to RT, quenched with $5 \% \mathrm{HCl}(5 \mathrm{ml})$ and diluted with $\mathrm{Et}_{2} \mathrm{O}(5 \mathrm{ml})$. The aqueous phase was extracted twice with $\mathrm{Et}_{2} \mathrm{O}(2 \times 5 \mathrm{ml})$. The organic layers were combined, washed once with $\mathrm{NaHCO}_{3}$, once with brine, dried over magnesium sulfate and filtered through Florisil. The solvent was removed in vacuo and the alkene purified by silica gel chromatography with hexane as the eluant.

\section{9.}

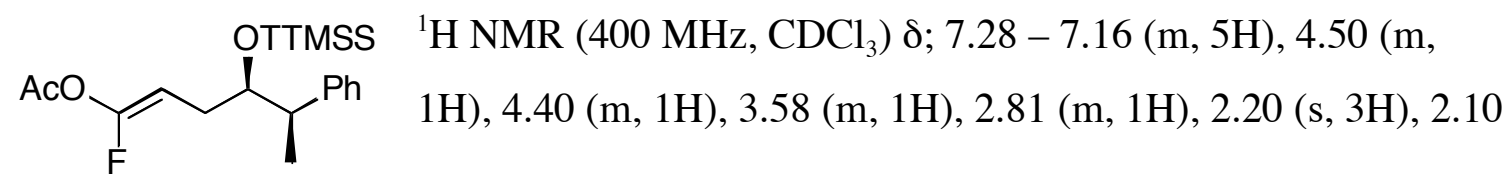


$(\mathrm{m}, 1 \mathrm{H}), 1.27(\mathrm{~d}, 3 \mathrm{H}, J=7.1 \mathrm{~Hz}), 0.19(\mathrm{~s}, 27 \mathrm{H}) ;{ }^{13} \mathrm{C} \mathrm{NMR}\left(125 \mathrm{MHz}, \mathrm{CDCl}_{3}\right) \delta ; 167.4$ $(\mathrm{d}, C F, J=20 \mathrm{~Hz}), 150.5(\mathrm{~d}, C F, J=288 \mathrm{~Hz}), 144.6,128.2,127.9,126.1,88.5$ (d, $C F, J$ $=25 \mathrm{~Hz}$ ), 79.9, 44.0, 28.2, 20.3, 17.3, 0.6; IR (film) 2960, 2894, 1742, 1463, 1381, 1244, 1070, 836; MS (EI) $\left(\mathrm{M}^{+}\right) 498.2$.

\section{Synthesis of $Z$-vinyl fluoride $10^{6}$}

$\mathrm{PBu}_{3}(940 \mu \mathrm{l}, 3.75 \mathrm{mmol})$ was dissolved in dichloromethane $(5 \mathrm{ml})$ and cooled to $0{ }^{\circ} \mathrm{C}$. $\mathrm{CCl}_{3} \mathrm{~F}(115 \mu \mathrm{l}, 1.25 \mathrm{mmol})$ was then added dropwise. The mixture was stirred at $0{ }^{\circ} \mathrm{C}$ for $1 \mathrm{~h}$ and then warmed to RT for $3 \mathrm{~h}$. While this salt was stirring at RT, The acetaldehyde super silyl enol ether (290 mg, 1 mmol) and 2-phenylpropanal (135 $\mu 1,1.0 \mathrm{mmol})$ were dissolved in dichloromethane $(2 \mathrm{ml})$ under nitrogen atmosphere and cooled to $-78{ }^{\circ} \mathrm{C}$. $\operatorname{HNTf}_{2}(100 \mu \mathrm{L}$ of a $5 \mathrm{mM}$ dichloromethane solution) was added dropwise and the reaction was stirred at $-78{ }^{\circ} \mathrm{C}$ for $15 \mathrm{~min}$. The in situ prepared aldehyde was then removed by syringe and added to the room temperature phosphoranium salt. The reaction was stirred for $12 \mathrm{~h}$ at room temperature. After this time, $1.5 \mathrm{ml}$ of $10 \% \mathrm{NaOH}$ was added and the mixture was stirred for $12 \mathrm{~h}$. The mixture was neutralized with $1 \mathrm{~N} \mathrm{HCl}$ and the aqueous layer extracted 3 times with dichloromethane $(3 \times 5 \mathrm{ml})$. The organic layers were combined and washed twice with $\mathrm{NaHCO}_{3}(2 \times 7 \mathrm{ml})$, once with brine and dried over sodium sulfate. Removal of the solvent in vacuo and column chromatography with hexane as the eluant gave $\mathbf{1 0 .}$

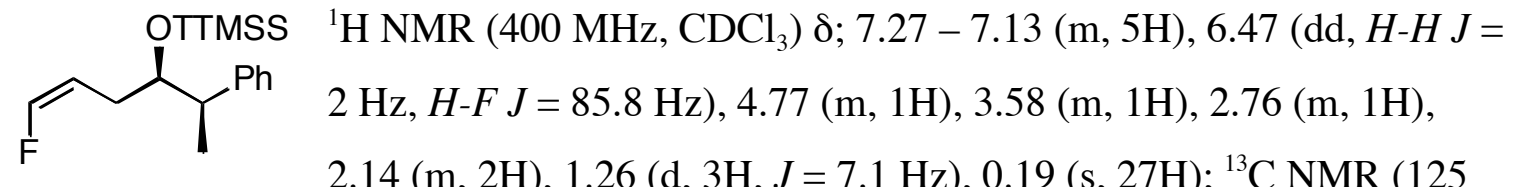

$$
2.14(\mathrm{~m}, 2 \mathrm{H}), 1.26(\mathrm{~d}, 3 \mathrm{H}, J=7.1 \mathrm{~Hz}), 0.19(\mathrm{~s}, 27 \mathrm{H}) ;{ }^{13} \mathrm{C} \text { NMR }(125
$$

$\left.\mathrm{MHz}, \mathrm{CDCl}_{3}\right) \delta ; 148.5(\mathrm{~d}, C F, J=263 \mathrm{~Hz}), 144.7,128.2,127.9,126.1,106.2(\mathrm{~d}, C F, J=$ $23 \mathrm{~Hz}$ ), 79.8, 44.1, 27.8, 17.0, 0.6; IR (film) 2960, 2894, 1463, 1381, 1244, 1070, 836; MS (EI) $\left(\mathrm{M}^{+}\right) 498.2$.

\section{Confirmation of Stereochemistry.}

1) Aldol reactions 
a. The aldol reaction of the acetaldehyde super silyl enol ether and 2-phenyl propanal have previously been shown to proceed with Felkin selectivity. ${ }^{\text {la }}$

b. The aldol reaction of the acetaldehyde super silyl enol ether and 2methylbutyraldehyde was confirmed to proceed with Felkin selectivity via the following reaction scheme with the final product matching the previously reported compound. ${ }^{7}$

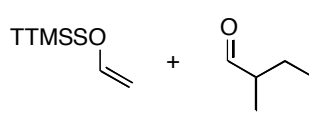

both match previously reported compounds
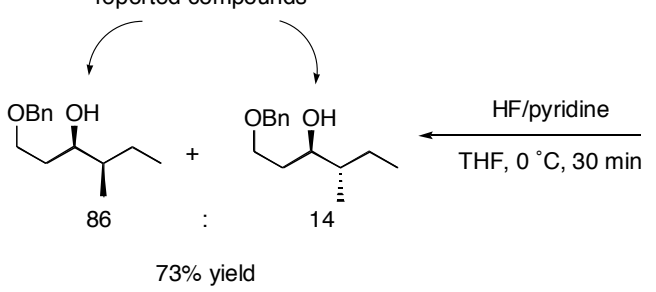

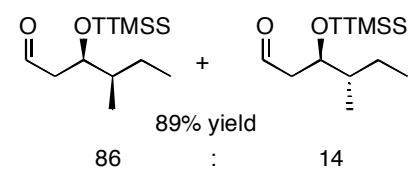

86 $\mathrm{NaBH}_{4}(4$ equiv) $\mathrm{MeOH}, 0{ }^{\circ} \mathrm{C}, 2 \mathrm{~h}$

2. benzyl 2,2,2-

trichloroacetimidate

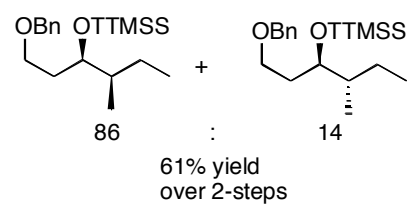

c. AAll diols were confirmed syn by cleavage of the silyl group with $\mathrm{HF} /$ pyridine and conversion to the acetonide in acetone with 10 equivalents of 2,2-dimethoxypropane with PPTS catalysis. The ${ }^{13} \mathrm{C}$ resonances for the acetonide methyl groups were in accord with the report by Rychnovsky. ${ }^{8}$

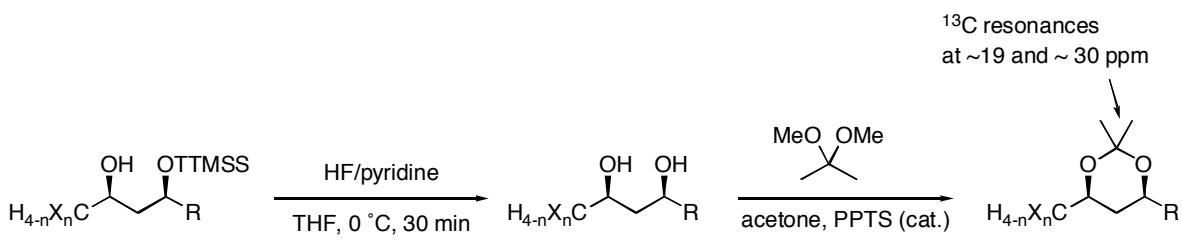

\section{References:}

1) a) M. B. Boxer, H. Yamamoto, J. Am. Chem. Soc. 2006, 128, 48 - 49 b) M. B. Boxer, H. Yamamoto, Nat. Protocols, 2006, 1, 2434 - 2438 
2) J. M. Concellón, H. Rodríguez-Solla, M. Huerta, J. A. Pérez-Andrés, Eur. J. Org. Chem. 2002, $1839-1847$.

3) B. C. Ranu, S. Samanta, A. Das, Tetrahedron Lett. 2002, 43, 5993 - 5995.

4) M. Kuroboshi, N. Yamada, Y. Takebe, T. Hiyama, Synlett, 1995, 987 - 988.

5) R. Bejot, S. Tisserand, L. M. Reddy, D. K. Barma, R. Baati, J. R. Falck, C. Mioskowski, Angew. Chem. Int. Ed. 2005, 44, 2008 - 2011; Angew. Chem. 2005, $117,2044-2047$.

6) D. G. Cox, N. Gurusamy, D. J. Burton, J. Am. Chem. Soc. 1985, 107, 2811 2812.

7) L. A. Flippin, P. A. Brown, K. Jalali-Araghi, J. Org. Chem. 1989, 54, 3588 3596.

8) S. D. Rychnovsky, B. Rogers, G. Yang, J. Org. Chem. 1993, 58, 3511 - 3515. 